\title{
Glutamine supplementation
}

\author{
Jan Wernerman
}

\begin{abstract}
Intravenous glutamine supplementation is standard care when parenteral nutrition is given for critical illness. There are data of a reduced mortality when glutamine supplementation is given. In addition, standard commercial products for parenteral nutrition do not contain any glutamine due to glutamine instability in aqueous solutions. For the majority of critical ill patients who are fed enterally, the available evidence is insufficient to recommend glutamine supplementation. Standard formulation of enteral nutrition contains some glutamine: $2-4 \mathrm{~g} / \mathrm{L}$. However, this dose is insufficient to normalize glutamine plasma concentration.

Plasma concentration of glutamine is low in many patients with critical illness and a low level is an independent risk factor for mortality. A low plasma glutamine concentration is the best indicator of glutamine depletion. Data are emerging about how the endogenous production of glutamine is regulated. We know that skeletal muscle is the major producer of glutamine and that a part of the profound depletion of skeletal muscle seen in critical illness is a reflection of the need to produce glutamine.

Glutamine is utilized in rapidly dividing cells in the splanchnic area. Quantitatively most glutamine is oxidized, but the availability of glutamine in surplus is important for the de novo synthesis of nucleotides and necessary for cell division and protein synthesis. More knowledge about the regulation of the endogenous production of glutamine is needed to outline better guidelines for glutamine supplementation in the future.
\end{abstract}

\section{Recommendation}

Presently the recommendation from ESPEN and ASPEN/SCCM is to add intravenous (IV) glutamine supplementation when total parenteral nutrition (TPN) is given to critically ill patients [1-3]. In all guidelines, this is given a level A recommendation. This evidence is based on several meta-analyses, and the recommendations also include a dose of glutamine of $0.3-0.5 \mathrm{~g} / \mathrm{kg} /$ day. This dose will normalize plasma glutamine concentration in almost all critically ill patients $[4,5]$.

The problem arises when the patients are fed differently than by TPN. This includes enteral nutrition, combined enteral and parenteral nutrition, and hypocaloric nutrition. An insufficient dose of glutamine may be added to these states. In all these settings, the existing evidence is less conclusive.

\section{Route of food administration}

Many colleges, investigators, and opinion-leaders feel that the route of nutrient administration makes a difference in critically ill patients. Usually the opinion is

Correspondence: jan.wernerman@karolinska.se

Department of Intensive Care Medicine, Karolinska University Hospital Huddinge, Karolinska Institutet, Stockholm, Sweden that enteral nutrition is superior to parenteral nutrition. This is probably true for infectious complications in patients randomized to enteral or parenteral nutrition, but no studies or meta-analyses demonstrate a mortality difference [6-10]. In fact the meta-analysis that demonstrates a difference, does so in favor of parenteral nutrition [10].

Numerous arguments may be given about why the design of studies that support the existing meta-analyses are not adequate: for example, only patients with a functional gastrointestinal tract were included; no glucose control; different caloric intake in groups; no dropout information; no blinding.

In the existing scoring systems for outcomes, there is no marker for gastrointestinal function. This is largely related to the absence of a suitable surrogate parameter for scoring. On the other hand, there is solid information that a successful enteral feeding, indicative of a functional gastrointestinal tract, is a predictor for a favorable outcome in patients with a similar mortality risk as estimated from the conventional scoring systems $[2,11,12]$. Success of enteral feeding may be enhanced by technical or pharmaceutical techniques, but presently there is very little evidence that such enhancement gives

\section{SpringerOpen ${ }^{\odot}$}


an outcome benefit even if it makes enteral nutrition more successful [13].

\section{Route of glutamine administration}

As stated earlier, IV glutamine supplementation of 0.3$0.5 \mathrm{~g} / \mathrm{kg} /$ day provides an improved outcome for patients on TPN [14-17]. This corresponds to an exogenous glutamine supplementation of 20-30 g/day, which normalizes the plasma concentration in most critcally ill patients $[4,5]$. Healthy subjects have an endogenous glutamine production of 50-80 g/day [18-21]. Most of the de novo glutamine synthesis takes place in skeletal muscle and is thereafter exported to the splanchnic area to be used mostly in enterocytes and immune cells [22,23]. In the critically ill, glutamine production is not altered, but the production is insufficient to keep up the plasma concentration $[20,24,25]$.

IV glutamine supplementation results in a uniform uptake of glutamine across the splanchnic area, similar to what happens with the endogenously produced glutamine. IV administration of glutamine is well characterized and the elimination rate from plasma is fast [4]. This pharmacokinetic profile makes it preferable to use a constant infusion for the IV glutamine supplementation. This may be as an additive to the parenteral nutrition or as a separate IV infusion of glutamine. In the latter case, this may be administered in a central or peripheral vein [26]. If a commercially available $20 \%$ glutamine containing dipeptide solution is used, the osmolarity is high (approximately $900 \mathrm{mosm} / \mathrm{L}$ ); however, because the $\mathrm{pH}$ is neutral, this does not irritate the peripheral veins.

In the case of enteral glutamine supplementation, the kinetics is much less well characterized [27]. Overall, the uptake of crystalline or dipeptide glutamine is fast and occurs in the upper part of the jejunum $[18,28]$. Only a fraction of the absorbed glutamine can be recovered in the portal blood. This is indicative of elimination in the gut, most likely in the enterocytes and immune cells present there. From portal blood through the liver into the systemic circulation another fraction of the absorbed glutamine is utilized in the liver. Therefore, the so-called first "pass elimination" is substantial: 40$90 \%$. It may be argued that this uptake is adequate, that the enterocytes and the immune cells actually are the targets for the endogenous glutamine production [22]. This is true, but at the same time, the complete uptake of the enterally administered glutamine in the upper part of the jejunum leaves the remaining part of the gastrointestinal tract unsupported by the enteral route. The effect on plasma glutamine concentration of an enterally administered glutamine supplementation is marginal [29-31]. So, after enteral glutamine supply, the low plasma concentration in critically ill is still low. It is highly likely that when enteral nutrition is not possible, a supply of parenterally administered glutamine becomes critical for the intestine. This may to some extent be compensated for by other amino acids when enteral nutrition is functional.

\section{Level of feeding}

The studies that demonstrate a favorable effect of glutamine are all studies where patients are fed according to their measured or estimated energy expenditure $[14,15,17]$. This is one possible explanation why studies with enterally supplemented patients on enteral nutrition have not been conclusive. For patients on parenteral nutrition, there are no reports employing a hypocaloric nutrition supplemented with glutamine.

It is well known that overfeeding critically ill patients may cause harm $[2,32]$. Overfeeding most often is practised when parenteral nutrition is given. Today this may be when large doses of lipid emulsion are given as a vehicle for drugs, or when enteral and parenteral nutrition is combined and the two routes of administration are not cleared between each other properly. Still if the caloric support is decided according to body weight, a considerable overfeeding may happen in individual cases. Adding glutamine supplementation may further boost the overfeeding. Measuring the energy expenditure by indirect calorimetry decreases the risk of overfeeding and enhances the quality of care in the ICU $[33,34]$.

\section{Plasma concentration}

The fact that glutamine deficiency defined as a low plasma concentration at ICU admittance is an independent mortality predictor $[35,36]$ makes it mandatory that future studies of exogenous glutamine supplementation define the patient groups studied in terms of glutamine deficiency. The original finding by OudemansVan Straaten et al. has been confirmed by subsequent studies [35]. It is true that plasma concentration is a poor indicator of intracellular depletion [37], which occurs postoperatively and in critical illness [5,38-40]. This depletion is however not uniform, but different in different cell types [41,42]. A conditional deficiency, as has been suggested, is best characterized by the plasma concentration. During the duration of ICU stay, plasma concentration only changes marginally [5].

To better define the degree of glutamine depletion and to enable a more precise selection of the patients in need of exogenous glutamine supplementation is necessary to be able to design study protocols that will give conclusive evidence [43]. The heterogeneity in patient groups studied, in particular studies of enteral supplementation, may be a major factor behind the inconclusive results [16]. 
Plasma glutamine concentration is presently the best determiner of glutamine depletion $[35,36]$. It is usually available and is related to outcome. There is no direct solid knowledge that normalization of plasma glutamine is associated with a better outcome; more than that we know that in the combined group of patients with a normal and/or a normalized plasma glutamine concentration there is a better outcome. More knowledge about the endogenous production of glutamine related to outcome and related to plasma glutamine concentration is needed, in particular when glutamine supplementation is given enterally.

\section{Possible adverse effects related to glutamine supplementation}

The only group of patients in the ICU with supranormal plasma glutamine concentration are patients with acute fulminant liver failure [44]. In contrast patients with chronic liver failure or acute-on-chronic liver failure have low or normal plasma glutamine concentrations and therefore they may be treated as any other patient in the ICU. On the other hand, the patient with acute fulminant liver failure may deserve some caution. Usually the history of disease is short and no malnutrition is at hand, therefore the indication for nutritional intervention is relative. The focus is usually on whether there will be a spontaneous remission or whether an acute liver transplantation will be needed. This decision is usually reached within a few days, so this group of patients does not constitute any major problem. A subgroup-insufficiently studied at present-are patients with acute liver failure after a liver resection with supervening complications. Here, we presently withhold glutamine supplementation waiting for more data.

Head trauma patients and other neurosurgical patients are another group that has been discussed because of the high interstitial concentration of glutamate, which in some observational studies have been associated with worse outcomes. The high interstitial glutamate concentration is mainly reported when microdialysis is done in the so-called penumbra zone, where there is an enhanced cell leakage. Glutamate is an excitatory transmitter and may therefore have effects in itself. In the intact brain, released glutamate is reabsorbed into nerve endings and is reutilized or taken up by astroglia and metabolized into glutamine. Hence, the brain is a net exporter of glutamine. When a supplementation dose of glutamine, on the level of the general recommendation, is given to head trauma patients, no change in the glutamate concentration of the microdialysis fluid can be detected [24]. Furthermore, there is no change in the net balance of glutamine or glutamine across the brain during supplementation [45]. Therefore, fear of an increase of cerebral interstitial glutamine concentration is no reason to abstain from glutamine supplementation. The predicted value of low plasma glutamine concentration or the value of glutamine supplementation on outcome has to our knowledge not been investigated in this particular patient group.

During dialysis or ultrafiltration, small molecules are lost to a higher degree compared with when urine is produced in a healthy kidney. Therefore, the question has been raised whether IV-supplemented glutamine will be lost in the dialysate in particular during continuous renal replacement therapy (CRRT), when the filtration is working around the clock. A recent study showed that all amino acids are lost during CRRT but not glutamine in particular [25]. Nevertheless, when CRRT is necessary the supplementation of glutamine should if anything be a little higher than usual: $0.5 \mathrm{~g} / \mathrm{kg} /$ day rather than $0.3 \mathrm{~g} / \mathrm{kg} /$ day.

\section{Comments on individual studies}

Two single-center studies provide the bulk of evidence for the recommendation to give IV glutamine supplementation when TPN is given $[14,15]$. Both studies are of good quality and involve mainly multiple organ failure patients with a longer ICU stay, but they were performed more than 10 years ago. Both studies show the same pattern, that a tendency toward a reduction in mortality during ICU stay became statistically significant as all-cause 6-month mortality. Both studies were comparatively small $(\mathrm{n}<100)$ and no glucose control was used in the clinical practice at that time. Other studies that are included in the present meta-analyses are of small size or include critically ill patients only as a part of the total patient material [16]. An overview of the cited studies is given in Table 1.

Studies of enterally administered glutamine supplementation to patients fed by enteral nutrition comprise a much more heterogenic patient group [29,30,46-50]. There are studies of exclusively trauma patients or burn patients, or there are studies that include a broad spectrum of critically ill patients with a wide range of diagnoses and consequently a very variable ICU length of stay. Not surprisingly the meta-analysis shows no mortality advantage but in many individual studies a morbidity advantage [16]. These studies represent an interpretation problem in several respects; in many cases a hypocaloric feeding, uncertainty concerning the utilization of the given supplementation, sometimes a considerable dilution effect from many included shortstayers with a low mortality rate, and a short treatment period [48].

An interesting study with a different concept uses an enteral product with key nutrients, including $30 \mathrm{~g}$ of glutamine per day. Some studies employing this product are small in size and mainly focus on safety [51]. One 
Table 1 Overview of cited randomized studies in ICU patients with glutamine supplementation

\begin{tabular}{|c|c|c|c|c|c|c|c|c|c|}
\hline Study & Year published & $\mathrm{n}$ & $\mathrm{MC} / \mathrm{SC}$ & Patients & EN/PN & Gln adm & Daily gln dose & Length of treatment ${ }^{*}$ & Treatment benefit \\
\hline Andrews [53] & 2011 & 502 & $M C$ & General ICU & $\mathrm{EN}+\mathrm{PN}$ & iv & $10-20 \mathrm{~g}$ & $5(1-10)$ & None \\
\hline Beale [29] & 2008 & 55 & SC & General ICU & EN & enteral & $40 \mathrm{~g}$ & $<10$ & Morbidity \\
\hline Conejero [46] & 2002 & 84 & $\mathrm{MC}$ & General ICU & EN & enteral & $35 \mathrm{~g}$ & $10(7-25)$ & Morbidity \\
\hline Garrel [47] & 2003 & 41 & SC & Burns & EN & enteral & $26 \mathrm{~g}$ & $30 \pm 17$ & Mortality \\
\hline Goeters [14] & 2002 & 95 & $M C$ & General ICU & $\mathrm{EN}+\mathrm{PN}$ & iv & $0.2 \mathrm{~g} / \mathrm{kg}$ & $17 \pm 11$ & Mortality \\
\hline Griffiths [15] & 1997 & 84 & SC & General ICU & PN & iv & $25 \mathrm{~g}$ & $6(2-91)$ & Mortality \\
\hline Hall [48] & 2003 & 363 & SC & General ICU & EN & enteral & $11-27 \mathrm{~g}$ & $10(6-16)$ & None \\
\hline Houdijk [30] & 1998 & 72 & SC & Trauma & EN & enteral & $27 \mathrm{~g}$ & $12 \pm 6$ & Morbidity \\
\hline Jones [49] & 1999 & 50 & SC & General ICU & EN & enteral & $18(11-21) \mathrm{g}$ & $11(3-47)$ & Morbidity \\
\hline Wernerman [17] & 2011 & 284 & $M C$ & General ICU & $\mathrm{EN}+\mathrm{PN}$ & iv & $0.28 \mathrm{~g} / \mathrm{kg}$ & $12(4-47)$ & Mortality \\
\hline Zhou [50] & 2003 & 40 & SC & Burns & EN & enteral & $0.35 \mathrm{~g} / \mathrm{kg}$ & 12 & Morbidity \\
\hline
\end{tabular}

$\mathrm{MC}=$ multi-center, $\mathrm{SC}=$ single-center, $\mathrm{EN}=$ enteral nutrition, $\mathrm{PN}=$ parenteral nutrition

*Values are medians (ranges) or means \pm SD

study in multiple organ failure patients, in whom administration of this product was possible, demonstrates an improvement in sequential SOFA scoring [29]. This is the most encouraging finding from enteral administration of glutamine supplementation.

A recent study in Scotland, the SIGNET trial, is the largest $(n=502)$ study of glutamine supplementation to critically ill patients to date $[52,53]$. The primary outcome variable was infection rate, and no benefit attributable to the glutamine supplementation was seen. Some concerns about the protocol have been addressed. Glutamine supplementation of $20 \mathrm{~g}$ was added into the allin-one bag containing 2,000 kcal used for parenteral nutrition. Patients were given IV nutrition from this bag whilst the enteral nutrition started in parallel. When more than $50 \%$ of the individual caloric target was given as enteral nutrition, the parenteral glutamine containing component was stopped. The result was short-term treatment (mean 5 days), and a low, not well-defined dose of glutamine. In addition, the treatment period was limited to a maximum of 10 days. The obvious limitations from the study make the negative result difficult to interpret.

A Scandinavian glutamine study also has been published recently [17]. In this study, the IV glutamine supplementation was given separate from the nutrition. Supplementation continued as long as patients stayed in the ICU. Patients were fully fed during the entire ICU period, in most cases using a combination of enteral and parenteral nutrition. Primary outcome variable was a difference in SOFA scoring. The study was planned for 1,000 patients, but was interrupted at 410 due to slow recruitment after 4 years. Primary outcome was not conclusive, but as secondary outcome ICU mortality was reduced in the treatment group. This reduction was, however, not sustained as 6-month all-cause mortality. This study is the first to combine enteral and parenteral nutrition. It may be hypothesized from the observation of an ICU mortality effect that continuation of glutamine supplementation also post-ICU may bring an outcome benefit.

In the pipeline there is a large North American-European study combining key nutrients, glutamine, and antioxidants, and combining enteral and parenteral routes for supplementation [54]. Results may be expected 1-2 years from now.

\section{Conclusions}

IV glutamine supplementation is standard care when parenteral nutrition is given in critical illness. For the majority of critical ill patients who are fed enterally, there is insufficient evidence for recommendations presently. Plasma concentration of glutamine is an independent risk factor for mortality in critical illness. So far, low plasma glutamine concentration is the best indicator of glutamine depletion. More knowledge about how the endogenous production of glutamine is regulated is needed to outline better guidelines for glutamine supplementation in the future.

\section{Competing interests}

The author declare no competing economic interests. Being the principal investigator of the Scandinavian Glutamine Trial, there is an academic competing interest, but that study was totally investigator-driven, without any commercial support.

Received: 12 April 2011 Accepted: 18 July 2011 Published: 18 July 2011

\section{References}

1. Anonymous: Guidelines for the use of parenteral and enteral nutrition in adult and pediatric patients. JPEN J Parenter Enteral Nutr 2002, 26:1S-138S.

2. Heyland DK, Dhaliwal R, Drover JW, Gramlich L, Dodek P: Canadian clinical practice guidelines for nutrition support in mechanically ventilated, critically ill adult patients. JPEN J Parenter Enteral Nutr 2003, 27:355-373.

3. Singer $P$, Berger MM, Van den Berghe $G$, Biolo $G$, Calder $P$, Forbes $A$, Griffiths R, Kreyman G, Leverve X, Pichard C: ESPEN Guidelines on Parenteral Nutrition: intensive care. Clin Nutr 2009, 28:387-400. 
4. Berg A, Rooyackers $\mathrm{O}$, Norberg A, Wernerman J: Elimination kinetics of Lalanyl-L-glutamine in ICU patients. Amino Acids 2005, 29:221-228.

5. Tjader I, Rooyackers O, Forsberg AM, Vesali RF, Garlick PJ, Wernerman J: Effects on skeletal muscle of intravenous glutamine supplementation to ICU patients. Intensive Care Med 2004, 30:266-275.

6. Gramlich L, Kichian K, Pinilla J, Rodych NJ, Dhaliwal R, Heyland DK: Does enteral nutrition compared to parenteral nutrition result in better outcomes in critically ill adult patients? A systematic review of the literature. Nutrition 2004, 20:843-848.

7. Heyland DK, MacDonald S, Keefe L, Drover JW: Total parenteral nutrition in the critically ill patient: a meta-analysis. JAMA 1998, 280:2013-2019.

8. Marik PE, Zaloga GP: Meta-analysis of parenteral nutrition versus enteral nutrition in patients with acute pancreatitis. BMJ 2004, 328:1407.

9. Peter JV, Moran JL, Phillips-Hughes J: A meta-analysis of treatment outcomes of early enteral versus early parenteral nutrition in hospitalized patients. Crit Care Med 2005, 33:213-220, discussion 260-211.

10. Simpson F, Doig GS: Parenteral vs. enteral nutrition in the critically ill patient: a meta-analysis of trials using the intention to treat principle. Intensive Care Med 2005, 31:12-23.

11. Doig GS, Heighes PT, Simpson F, Sweetman EA, Davies AR: Early enteral nutrition, provided within $24 \mathrm{~h}$ of injury or intensive care unit admission, significantly reduces mortality in critically ill patients: a metaanalysis of randomised controlled trials. Intensive Care Med 2009, 35:2018-2027.

12. Marik PE, Zaloga GP: Early enteral nutrition in acutely ill patients: a systematic review. Crit Care Med 2001, 29:2264-2270.

13. Marik PE, Zaloga GP: Gastric versus post-pyloric feeding: a systematic review. Crit Care 2003, 7:R46-51.

14. Goeters C, Wenn A, Mertes N, Wempe C, Van Aken H, Stehle P, Bone HG: Parenteral L-alanyl-L-glutamine improves 6 -month outcome in critically ill patients. Crit Care Med 2002, 30:2032-2037.

15. Griffiths RD, Jones C, Palmer TE: Six-month outcome of critically ill patients given glutamine-supplemented parenteral nutrition. Nutrition 1997, 13:295-302.

16. Novak F, Heyland DK, Avenell A, Drover JW, Su X: Glutamine supplementation in serious illness: a systematic review of the evidence. Crit Care Med 2002, 30:2022-2029.

17. Wernerman J, Kirketeig $T$, Andersson B, Berthelson $H$, Ersson A, Friberg $H_{\text {, }}$ Guttormsen AB, Hendrikx S, Pettila V, Rossi P, Sjoberg F, Winso O: Scandinavian Glutamine Trial: a Pragmatic Clinical Multi-Centre RCT of ICU patients. Acta Anaesth Scand 2011.

18. Darmaun D, Just B, Messing B, Rongier M, Thuillier F, Koziet J, Grasset E: Glutamine metabolism in healthy adult men: response to enteral and intravenous feeding. Am J Clin Nutr 1994, 59:1395-1402.

19. Darmaun D, Matthews DE, Bier DM: Glutamine and glutamate kinetics in humans. Am J Physiol 1986, 251:E117-126.

20. Gore DC, Jahoor F: Glutamine kinetics in burn patients. Comparison with hormonally induced stress in volunteers. Arch Surg 1994, 129:1318-1323.

21. Van Acker BA, Hulsewe KW, Wagenmakers AJ, Deutz NE, Van Kreel BK, Halliday D, Matthews DE, Soeters PB, Von Meyenfeldt MF: Absence of glutamine isotopic steady state: implications for the assessment of whole-body glutamine production rate. Clin Sci (Lond) 1998, 95:339-346.

22. Newsholme EA, Calder PC: The proposed role of glutamine in some cells of the immune system and speculative consequences for the whole animal. Nutrition 1997, 13:728-730.

23. Newsholme EA, Carrie AL: Quantitative aspects of glucose and glutamine metabolism by intestinal cells. Gut 1994, 35:S13-17.

24. Berg A, Bellander BM, Wanecek M, Gamrin L, Elving A, Rooyackers O, Ungerstedt $\mathrm{U}$, Wernerman J: Intravenous glutamine supplementation to head trauma patients leaves cerebral glutamate concentration unaffected. Intensive Care Med 2006, 32:1741-1746.

25. Berg A, Norberg A, Martling CR, Gamrin L, Rooyackers O, Wernerman J: Glutamine kinetics during intravenous glutamine supplementation in ICU patients on continuous renal replacement therapy. Intensive Care Med 2007, 33:660-666.

26. Berg A, Forsberg E, Wernerman J: The local vascular tolerance to an intravenous infusion of a concentrated glutamine solution in ICU patients. Clin Nutr 2002, 21:135-139.

27. Dechelotte P, Darmaun D, Rongier M, Hecketsweiler B, Rigal O, Desjeux JF: Absorption and metabolic effects of enterally administered glutamine in humans. Am J Physiol 1991, 260:G677-682.
28. Claeyssens S, Bouteloup-Demange C, Gachon P, Hecketsweiler B, Lerebours E, Lavoinne A, Dechelotte P: Effect of enteral glutamine on leucine, phenylalanine and glutamine metabolism in hypercortisolemic subjects. Am J Physiol Endocrinol Metab 2000, 278:E817-824.

29. Beale RJ, Sherry T, Lei K, Campbell-Stephen L, McCook J, Smith J, Venetz W, Alteheld B, Stehle P, Schneider H: Early enteral supplementation with key pharmaconutrients improves Sequential Organ Failure Assessment score in critically ill patients with sepsis: outcome of a randomized, controlled, double-blind trial. Crit Care Med 2008, 36:131-144.

30. Houdijk AP, Rijnsburger ER, Jansen J, Wesdorp RI, Weiss JK, McCamish MA, Teerlink T, Meuwissen SG, Haarman HJ, Thijs LG, van Leeuwen PA: Randomised trial of glutamine-enriched enteral nutrition on infectious morbidity in patients with multiple trauma. Lancet 1998, 352:772-776.

31. Melis GC, Boelens PG, van der Sijp JR, Popovici T, De Bandt JP, Cynober L, van Leeuwen PA: The feeding route (enteral or parenteral) affects the plasma response of the dipetide Ala-Gln and the amino acids glutamine, citrulline and arginine, with the administration of Ala-Gln in preoperative patients. Br J Nutr 2005, 94:19-26.

32. Krishnan JA, Parce PB, Martinez A, Diette GB, Brower RG: Caloric intake in medical ICU patients: consistency of care with guidelines and relationship to clinical outcomes. Chest 2003, 124:297-305.

33. Dvir $\mathrm{D}$, Cohen J, Singer P: Computerized energy balance and complications in critically ill patients: an observational study. Clin Nutr 2005, 25:37-44

34. Singer P, Anbar R, Cohen J, Shapiro H, Shalita-Chesner M, Lev S, Grozovski E, Theilla M, Frishman S, Madar Z: The Tight Calorie Control Study (TICACOS): a prospective, randomized, controlled pilot study of nutritional support in critically ill patients. Intensive Care Med 2011, 27.

35. Oudemans-van Straaten HM, Bosman RJ, Treskes M, van der Spoel HJ, Zandstra DF: Plasma glutamine depletion and patient outcome in acute ICU admissions. Intensive Care Med 2001, 27:84-90.

36. Rodas PC, Rooyackers $\mathrm{O}$, Hebert C, Norberg A, Wernerman J: Glutamine and glutathione at ICU admission in relation to outcome. Critical Care 2011 .

37. Kuhn KS, Schuhmann K, Stehle P. Darmaun D, Furst P. Determination of glutamine in muscle protein facilitates accurate assessment of proteolysis and de novo synthesis-derived endogenous glutamine production. Am J Clin Nutr 1999, 70:484-489.

38. Gamrin L, Essen P, Forsberg AM, Hultman E, Wernerman J: A descriptive study of skeletal muscle metabolism in critically ill patients: free amino acids, energy-rich phosphates, protein, nucleic acids, fat, water, and electrolytes. Crit Care Med 1996, 24:575-583.

39. Hammarqvist F, Wernerman J, Ali R, von der Decken A, Vinnars E: Addition of glutamine to total parenteral nutrition after elective abdominal surgery spares free glutamine in muscle, counteracts the fall in muscle protein synthesis, and improves nitrogen balance. Ann Surg 1989, 209:455-461.

40. Roth E, Funovics J, Muhlbacher F, Schemper M, Mauritz W, Sporn P, Fritsch A: Metabolic disorders in severe abdominal sepsis: glutamine deficiency in skeletal muscle. Clin Nutr 1982, 1:25-41.

41. Ahlman B, Ljungqvist O, Persson B, Bindslev L, Wernerman J: Intestinal amino acid content in critically ill patients. JPEN J Parenter Enteral Nutr 1995, 19:272-278.

42. Barle H, Ahlman B, Nyberg B, Andersson K, Essen P, Wernerman J: The concentrations of free amino acids in human liver tissue obtained during laparoscopic surgery. Clin Physiol 1996, 16:217-227.

43. Wernerman J: Glutamine to intensive care unit patients. JPEN J Parenter Enteral Nutr 2003, 27:302-303.

44. Clemmesen JO, Kondrup J, Ott P: Splanchnic and leg exchange of amino acids and ammonia in acute liver failure. Gastroenterology 2000, 118:1131-1139.

45. Berg A, Bellander BM, Wanecek M, Norberg A, Ungerstedt U, Rooyackers $\mathrm{O}$, Wernerman J: The pattern of amino acid exchange across the brain is unaffected by intravenous glutamine supplementation in head trauma patients. Clin Nutr 2008.

46. Conejero R, Bonet A, Grau T, Esteban A, Mesejo A, Montejo JC, Lopez J, Acosta JA: Effect of a glutamine-enriched enteral diet on intestinal permeability and infectious morbidity at 28 days in critically ill patients with systemic inflammatory response syndrome: a randomized, singleblind, prospective, multicenter study. Nutrition 2002, 18:716-721. 
47. Garrel D, Patenaude J, Nedelec B, Samson L, Dorais J, Champoux J, D'Elia M, Bernier J: Decreased mortality and infectious morbidity in adult burn patients given enteral glutamine supplements: a prospective, controlled, randomized clinical trial. Crit Care Med 2003, 31:2444-2449.

48. Hall JC, Dobb G, Hall J, de Sousa R, Brennan L, McCauley R: A prospective randomized trial of enteral glutamine in critical illness. Intensive Care Med 2003, 29:1710-1716.

49. Jones C, Palmer TE, Griffiths RD: Randomized clinical outcome study of critically ill patients given glutamine-supplemented enteral nutrition. Nutrition 1999, 15:108-115.

50. Zhou YP, Jiang ZM, Sun YH, Wang XR, Ma EL, Wilmore D: The effect of supplemental enteral glutamine on plasma levels, gut function, and outcome in severe burns: a randomized, double-blind, controlled clinical trial. JPEN J Parenter Enteral Nutr 2003, 27:241-245.

51. Schroeder J, Alteheld B, Stehle P, Cayeux MC, Chiolero RL, Berger MM: Safety and intestinal tolerance of high-dose enteral antioxidants and glutamine peptides after upper gastrointestinal surgery. Eur J Clin Nutr 2005, 59:307-310.

52. Andrews PJ, Avenell A, Noble DW, Campbell MK, Battison CG, Croal BL, Simpson WG, Norrie J, Vale LD, Cook J, de Verteuil R, Milne AC:

Randomised trial of glutamine and selenium supplemented parenteral nutrition for critically ill patients. Trials 2007, 8:25, Protocol Version 9, 19 February 2007 Known as SIGNET (Scottish Intensive care Glutamine or seleNium Evaluative Trial).

53. Andrews PJ, Avenell A, Noble DW, Campbell MK, Croal BL, Simpson WG, Vale LD, Battison CG, Jenkinson DJ, Cook JA: Randomised trial of glutamine, selenium, or both, to supplement parenteral nutrition for critically ill patients. BMJ 2011, 342:d1542.

54. Heyland DK, Dhaliwal R, Day AG, Muscedere J, Drover J, Suchner U, Cook D: REducing Deaths due to OXidative Stress (The REDOXS Study): Rationale and study design for a randomized trial of glutamine and antioxidant supplementation in critically-ill patients. Proc Nutr Soc 2006, 65:250-263.

doi:10.1186/2110-5820-1-25

Cite this article as: Wernerman: Glutamine supplementation. Annals of Intensive Care 2011 1:25.

\section{Submit your manuscript to a SpringerOpen ${ }^{\circ}$ journal and benefit from:}

- Convenient online submission

- Rigorous peer review

- Immediate publication on acceptance

- Open access: articles freely available online

- High visibility within the field

- Retaining the copyright to your article

Submit your next manuscript at $\gg$ springeropen.com 